\title{
Biochemical profiling of antifungal activity of betel leaf (Piper betle L.) extract and its significance in traditional medicine
}

\author{
Sarika Pawar ${ }^{1 \#,}$ Vidya Kalyankar ${ }^{2}$, Bela Dhamangaonkar ${ }^{1}$, Sharada Dagade ${ }^{3}$, \\ Shobha Waghmode ${ }^{2 *}$ and Abhishek Cukkemane ${ }^{1}$ \\ ${ }^{1}$ Bijasu Agri Research Laboratory LLP, Sr. No. 37, Kondhwa Industrial Estate, Khadi Machine Chowk, Kondhwa, Pune-411048, India \\ ${ }^{2}$ Department of Chemistry, M. E. S Abasaheb Garware College, Pune - 411 007, Maharashtra, India \\ ${ }^{3}$ Department of Chemistry, Y. M. College, Bharathi Vidyapeeth, Pune-411038, Maharashtra, India \\ \#Present Address: Microbial Diversity Research Centre, Dr. D. Y. Patil Biotechnology and Bioinformatics Institute, Dr. D. Y. Patil Vidyapeeth, Tathawade, Pune-
} 411033, India

Received: 13 February, 2017; Accepted: 10 March, 2017; Published: 20 March, 2017

*Corresponding author: ShobhaWaghmode, Department of Chemistry, M. E. S Abasahaeb garware College, Pune - 411 007, Maharashtra, India; Tel. No: +91-9422-31-6985; E-mail: shobhawaghmode@yahoo.co.in

\begin{abstract}
Piper betle (Linn) commonly called as betel leaf is a widely cultivated plant in the Indian subcontinent. The traditional Indian ayurvedic document describes several of its medicinal properties including as an effective antifungal agent. The present study was conducted to evaluate the secondary metabolite that contributes to its antifungal activity. Invitro studies were performed on molds and yeasts on antifungal using fractions obtained from ethyl acetate, hexane and ethanol-methanol extracts by well-diffusion technique. Ethyl acetate extracts showed highest anti-fungal activity. Using biophysical techniques such as Nuclear Magnetic Resonance and Fourier transform infrared spectroscopy techniques; we identified the molecule as derivative of the phenyl propanoid family akin eugenol. The molecule can be readily purified using a 2 step solvent extraction procedure along with silica column chromatography. These findings reveal the antifungal and possible commercial potential of the plant extract and its potential in agriculture against pest management and food spoilage.
\end{abstract}

Aim: To determine the antifungal activity of Piper betle L. extracts.

Keywords: Antifungal; Ayurveda; Fourier transform infra-red spectroscopy; Nuclear magnetic resonance spectroscopy; Food spoilage; Agriculture.

\section{Introduction}

In recent years, the increase in resistance in known fungal pathogens to the available antifungal drugs has raised enormous challenges to public health issues [1-3]. In addition, conventional antifungal drugs have undesirable side effects and are very toxic such as chlorhexidine, imidazole and amphotericin B [4]. One important demand of critical significance in this context is to search for novel antifungal agents that would be less toxic and more effective. Interestingly; several medicinal plants have been extensively investigated in order to find novel bioactive compounds [5]. Moreover, several studies have suggested that a number of plant species possesses promising antimicrobial compounds [6-9]. Piper betle Linn. (Piperaceae), a slender creeping plant, is widely distributed in India, Sri Lanka, Thailand and other tropical countries. This plant has deep green heart shaped, smooth, shinning and long stalked leaves, with pointed apex. Betel leaf possess strong aromatic flavor and have been long in use for the preparation of traditional Indian ayurvedic herbal remedies. It has been reported for the treatment of various diseases such as conjunctivitis, boils and abscesses, cuts and injuries etc. [5,10]. In addition, it also acts as a breath freshener, a digestive and pancreatic lipase stimulant and a pain killer in joint pain $[11,13]$. Even though all these positive effects of betel leaf are known, the biochemicals of these favorable effects remain obscure. Moreover, betel leaf extract has previously been shown to have strong antimicrobial effects in review [14-19]. A couple of research articles $[20,21]$ have demonstrated the potential of the leaf extract on dermatophytes. Here in, we show that the leaf extract possess antifungal activity against various plant pathogens. The present study was sought to investigate the effects of ethyl acetate, hexane and ethanol-methanol extracts of this plant leave on fungal pathogens.

Here in, we employed biophysical techniques to identify the active metabolite that provide the betel leaf extract with its anti-fungal and other pharmacological properties that have been valued in traditional Indian ayurveda.

\section{Materials and methods}

\section{Betel leaf extract}

The crude extract and isolation was done using Silica Gel (100-200 mesh) for column chromatography and HPLC grade solvents. Betel leaf was collected from Western Maharashtra farm (Indapur tehsil), India. It was cleaned first with distilled water 
and dried in shadow for a week. The dried leaves were powdered and $100 \mathrm{~g}$ was used for extraction. The powder was transferred into $1 \mathrm{~L}$ conical flask with $500 \mathrm{~mL}$ ethanol to completely soak the powder, which was incubated at room temperature for 24 hours. The sample was filtered using ordinary filter paper directly into the clean round bottom flask and set for distillation. We obtained up to $30 \mathrm{~mL}$ of distillate from a single run under controlled heating at $55^{\circ} \mathrm{C}$ under reduced pressure. We repeated the procedure 3 times and pulled the collected distillate containing crude extract. The crude extract was concentrated on a water bath at $55^{\circ} \mathrm{C}$ under reduced pressure.

During the extraction optimization step, we added $100 \mathrm{~mL}$ ethyl acetate/ethanol-methanol/ hexane to the concentrated $100 \mathrm{~mL}$ crude extract and mixed well. The mixture was separate during separating funnel and the ethyl acetate/n-hexane fraction was collected in another conical flask. All 3 extracts were concentrated in procedure mentioned above and was further purified using column chromatography using the respective solvent .The eluent was pooled and analyzed by thin-layered chromatography (TLC), Silica gel 60 F254, preloaded Silica gel on Alumina sheets with ethyl acetate as the solvent and observed under UV chamber and Iodine vapors.

\section{Fungal strains and growth conditions}

We tested the effect of betel leaf extract on opportunistic fungal pathogen Aspergillus niger, which is the causative agent of black mold in several fruits and vegetables [22]. We also isolated saprophytic and opportunistic pathogenic fungi Rhizopus $s p$. [23] from the leaves of Murraya koenigii. (curry leaves). Lastly, we isolated a mold from the leaf of figs infested with rust, which was not obligate parasite Cerotelium (Physopella) fici [24] but we have tentatively identified it as wild Aspergillus sp. These cultures were cultured and maintained on Potato Dextrose Agar (PDA- HIMEDIA) at $4{ }^{\circ} \mathrm{C}$. A stock inoculums spore suspension of each fungal culture was prepared from fresh, mature (3-daysold) cultures grown on potato dextrose agar plates at $28^{\circ} \mathrm{C}$.

\section{In-vitro antifungal assay}

Antifungal activity of betel leaf extract was tested against A.niger, wild Aspergillus sp. and Rhizopus sp. of the ethyl acetate, hexane and ethanol-methanol extracts of betel leaf sample was tested by well diffusion method. In brief, $500 \mu \mathrm{L}$ of fungal spore suspension was added to $20 \mathrm{~mL}$ PDA medium and poured in petri dish. After solidification, wells of $5 \mathrm{~mm}$ in diameter were made on this plate. Each well was filled with $50 \mu \mathrm{L}$ of ethyl acetate, hexane and ethanol-methanol herbal extract. Potassium tellurite was used as positive control and ethyl acetate, hexane and ethanolmethanol solvent used as negative control. The antifungal assay plates were incubated at $30^{\circ} \mathrm{C}$ for $36 \mathrm{~h}$. The antifungal activities of the extracts were determined by measuring the diameter of the inhibition zone in millimetres $(\mathrm{mm})$.

\section{NMR and FTIR}

The IR spectra of neat sample were recorded on Nicolette iD5, Thermo scientific at room temperature. Standard ${ }^{1} \mathrm{H}$ NMR spectra was recorded on Jeol $200 \mathrm{MHz}$ using $\mathrm{CDCl}_{3}$ solvent and TMS (Euriso-top) as a reference at room temperature.

\section{Results}

\section{Isolation of active ingredient from Piper betle extract}

The beetle leaf extract was purified to homogeneity. During the solvent extraction steps, we observed three spots on the TLC plates. After solvent extraction the crude extract was concentrated and run on a column containing 100-200 mesh Silica Gel and Sodium Sulfate for further purification. In all three solvent types that we tested we observed a single spot from there fraction.

\section{Antifungal susceptibility assay}

In the next step, we studied the effect of the organic extract against a range of bacterial and fungal cultures. In all tested cases, we observed antimicrobial effect of the extract against fungal cultures only. This is in stark contrast to preciously reported data where few groups have observed anti-bacterial effect of the Piper betle extract $[14,17,25,26]$. Results obtained in the present study revealed that the ethyl acetate extract possess effective antifungal activity against all the tested fungal cultures (Table-1, Figure-1).The highest antifungal activity of ethyl acetate extract was observed for A.niger and Black rust followed by Rhizopus $s p$. Antifungal activity of hexane extract was also significant against A.niger ( $5 \mathrm{~mm}$ ) and Aspergillus sp. ( $8 \mathrm{~mm}$ ), while ethanolmethanol extract was ineffective against any of the tested fungal cultures. In addition to the molds, we also tested the effects of wild yeasts that were isolated from leaves. We again noticed a strong anti-fungal activity against them. From all the preparations, ethyl acetate fraction provided the best results. This could be because the extraction process is more efficient and perhaps also stable over other solvent.

\section{Biophysical characterization of the extract}

\begin{tabular}{|c|c|c|c|c|}
\hline \multicolumn{1}{|l|}{ Table 1 } & \multicolumn{4}{|c|}{ Inhibition zone (mm) } \\
\hline Fungal culture & $\begin{array}{c}\text { Ethyl } \\
\text { acetate }\end{array}$ & Hexane & $\begin{array}{c}\text { Ethanol- } \\
\text { Methanol }\end{array}$ & $\begin{array}{c}\text { K-tellurite } \\
\text { (+ control) }\end{array}$ \\
\hline Aspergillus niger & 28 & 5 & - & 6 \\
\hline Aspergillus sp. & 28 & 8 & - & 7 \\
\hline Rhizopus sp. & 23 & - & - & - \\
\hline
\end{tabular}

Antifungal activity of ethyl acetate, hexane and ethanol-methanol herbal extract against indicated fungi.

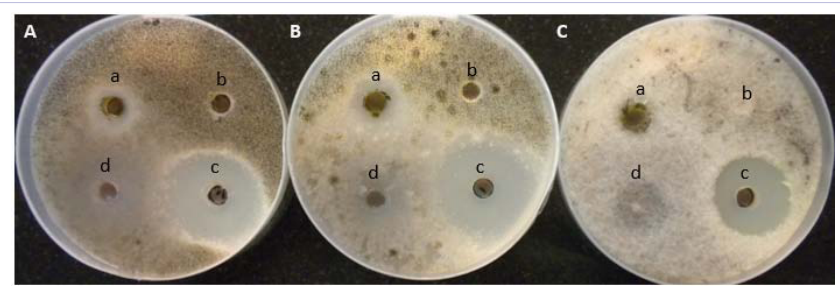

Figure 1: Antifungal activity of ethyl acetate, hexane and ethanol-methanol extracts of herbal sample against A) A.niger B) Aspergillus sp. and C) Rhizopus. Extract preparation in a) Hexane, b) Ethanol-Methanol, c) Ethyl acetate and positive control d) Potassium tellurite 
We performed NMR and FTIR spectroscopy in order to understand the functional groups associated with the isolated active compound. In the ${ }^{1} \mathrm{H}-\mathrm{NMR}$ spectrum, we observed three types downfield peaks at 6.7, 7.2 and $7.25 \mathrm{ppm}$ for aromatic ring. Additionally plenty of peaks were observed for protons associated with polar and aliphatic groups in the 3.25-5.5 and 1-2.25 ppm, respectively. From the characteristics of the spectra and the results published by other groups, the extracted compound is a derivative of the phenyl propanoid family to which antimicrobials eugenol-chavicol belong [27]. The FTIR spectra well corroborated with the NMR spectrum. We observed a broad peak in the range of 3700 to 3000 , which corresponds to absorption caused by $\mathrm{N}-\mathrm{H}, \mathrm{C}-\mathrm{H}$ and $\mathrm{O}-\mathrm{H}$ single bonds. We did not observe any peaks characteristic of triple bonds in the range of 2,500 to 2,000. A wide range of double bond specific groups in $\mathrm{C}=\mathrm{O}$ and $\mathrm{C}=\mathrm{C}$ was observed in the region from 2,000 to 1,500 . Lastly, the region from $1700-600$ show finger print that is reminiscent of phenyl propanoid eugenol $[27,28]$.

\section{Discussion}

The antifungal activity of the various extract highlights that ethyl acetate based extraction process provided the best for antifungal property. Surprisingly, unlike other results where Piperbetle extract that showed both anti- bacterial and fungal activities, we did not observe any anti-bacterial effect against gram positive Staphylococcus aureus and Bacillus sp.; few gram negative bacteria such as Escherichia coli, Pseudomonas aeruginosa and Xanthomonas campestris. This may be due to the fact that our purification method is different to the ones reported before (Table 2). In all previous studies crude extracts have been used hence many groups have reported anti-bacterial, anti-fungal and in some cases anti-cancer effects as well. In

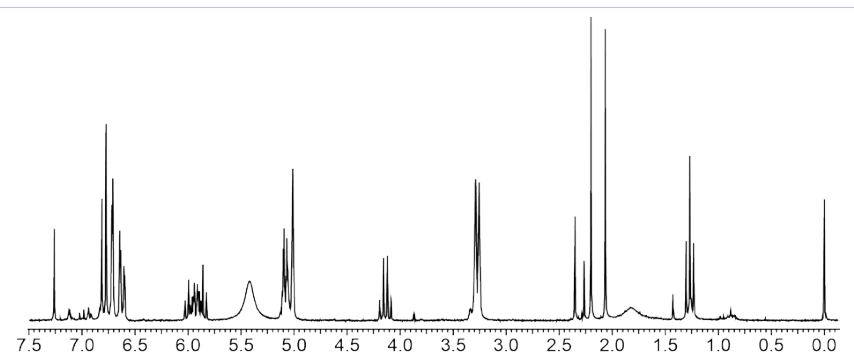

Figure 2: $1 \mathrm{D}{ }^{1} \mathrm{H}-\mathrm{NMR}$ spectrum of the active ingredient of Piper betle extract is suggestive of molecule from the phenyl propanoid- eugenol family

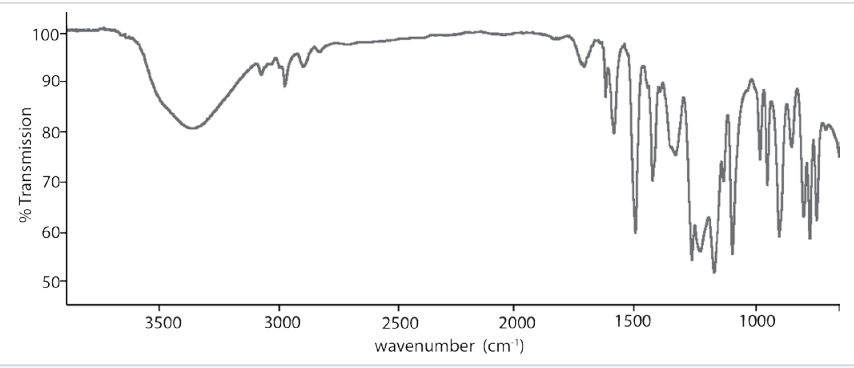

Figure 3: FTIR spectrum of the active ingredient of Piper betle extract.

\begin{tabular}{|c|c|c|}
\hline \multicolumn{3}{|l|}{ Table 2} \\
\hline $\begin{array}{c}\text { Active } \\
\text { compound }\end{array}$ & Extraction method & Result \\
\hline \multirow[t]{3}{*}{ Hydroxychavicol } & choloroform extract & $\begin{array}{c}\text { anti-fungal (Ali et al., } \\
\text { 2010); } \\
\text { antibacterial (Sharma et al } \\
2009 \text { ) }\end{array}$ \\
\hline & hydrodistillation & $\begin{array}{c}\text { anti-bacterial (Basak and } \\
\text { Guha, 2015) }\end{array}$ \\
\hline & $\begin{array}{l}\text { Concoction- boiling } \\
\text { extraction }\end{array}$ & $\begin{array}{c}\text { anti-cancer (Gundala et al., } \\
2014 \text { ) }\end{array}$ \\
\hline \multirow[t]{3}{*}{ Eugenol } & $\begin{array}{l}\text { ethanol or water- } \\
\text { soxhlet extraction }\end{array}$ & $\begin{array}{c}\text { Streptococcus mutans } \\
\text { (Deshpande and Kadam, } \\
\text { 2013) }\end{array}$ \\
\hline & $\begin{array}{l}\text { solvent extraction: } \\
\text { methanol, ethyl acetate } \\
\text { and petroleum ether }\end{array}$ & $\begin{array}{c}\text { Streptococcus mutans } \\
\text { (Deshpande and Kadam, } \\
\text { 2015) }\end{array}$ \\
\hline & hydro-distillation & $\begin{array}{c}\text { anti-bacterial (Sugumaran } \\
\text { et al., 2011) }\end{array}$ \\
\hline \multirow[t]{2}{*}{$\begin{array}{l}\text { Hydroxychavicol } \\
\text { and Eugenol }\end{array}$} & methanolic extract & $\begin{array}{c}\text { anti-cancer (Paranjpe et al., } \\
2013 \text { ) }\end{array}$ \\
\hline & $\begin{array}{l}\text { liquid-liquid and } \\
\text { supercritical fluid } \\
\text { extraction }\end{array}$ & $\begin{array}{c}\text { Comparison of extraction } \\
\text { methods(Singtongratana et } \\
\text { al., 2013) }\end{array}$ \\
\hline
\end{tabular}

Summary of bio-active extraction procedures from Piper betle

our methodology, we have enriched the phenyl propoanoid derivative in the extract by first ethanolic extract and then treating with other organic solvents like ethyl acetate/ hexane/ ethanol-methanol. Furthermore, the large zone of clearance that we observe highlights the better extraction and stability of the phenyl propanoid in the ethyl acetate fraction.

\section{Conclusion}

Our finding sheds light on one of the important biochemical metabolite that contributes to the significance of betel leaf in traditional Indian ayurvedic medicine. The metabolite can be readily extracted in a two-step process using organic solvents and silica column chromatography. The active ingredient belongs to the phenyl propanoid family belonging to eugenolchavicol group have been shown to possess strong antimicrobial properties $[15,26,29,30]$. More importantly, our results highlight the potential of using betel leaf extract as a potent anti-fungal agent for farming and perhaps also food storage against different types of molds. Food spoilage is a major agricultural problem accounting for heavy losses; therefore it is necessary to make the process commercially viable and efficacious against various pathogens and food spoilage organisms [31,32].

\section{Acknowledgements}

We thank the following institutes like.M.E.S AbasahebGarware college, Vijay Chemicals and Neeti Developer for support; and Dr. Nivedita Cukkemane for critically reading the manuscript.

\section{References}

1. Alexander BD, Perfect JR, Antifungal resistance trends towards the year 2000. Implications for therapy and new approaches. Drugs. 1997;54(5):657-678. 
2. Ghannoum MA, Rice LB, Antifungal agents: mode of action, mechanisms of resistance, and correlation of these mechanisms with bacterial resistance. Clin Microbiol Rev. 1999;12(4):501-517.

3. Neely MN, Ghannoum MA. The exciting future of antifungal therapy Eur J Clin Microbiol Infect Dis. 2000; 19(12):897-914.

4. White TC, Marr KA, Bowden RA, 1998. Clinical, cellular and molecular factors that contribute to antifungal drug resistance. Clin Microbiol. 1998;11(2):382-402.

5. Peter KV. Handbook of herbs and spices. $1^{\text {st }}$ Edition Vol 1 and Vol 2. Sawston, Cambridge: Woodhead Publishing Limited;2004.

6. Nakamura CV, Ishida K, Faccin LC, Filho BPD, Cortez DAG, Rozenta $\mathrm{S}$, et al. In vitro activity of essential oil from Ocimum gratissimum L. against four Candida species. Res Microbiol. 2004;155(7):579-586. doi:10.1016/j.resmic.2004.04.004

7. Wannissorn B, Jarikasem S, Siriwangchai T, Thubthimthed S. Antibacterial properties of essential oils from Thai medicinal plants. Fitoterapia. 2005;76(2):233-236.

8. Khan R, Islam B, Akram M, Shakil S, Ahmad A, Ali SM, et al. Antimicrobial Activity of Five Herbal Extracts Against Multi Drug Resistant (MDR) Strains of Bacteria and Fungus of Clinical Origin. Molecules. 2009;14(2):586-597. doi: 10.3390/molecules14020586

9. Jagtap SD, Deokule SS, Pawar PK, Harsulkar AM, Kuvalekar A A. Antimicrobial activity of some crude herbal drugs used for skin diseases by Pawra tribes of Nandurbar district. J Nat Prod. 2010;1(2):216-220.

10. Guha P. Betel leaf: The Neglected Green Gold of India. J Hum Ecol. 2006;19(2):87-93.

11. Norton SA. Betle: consumption and consequences. J Am Acad Dermatol. 1998;38(1):81-88.

12. Prabhu MS, Patel K, SaraawathiG, Srinivasan K, Effect of orally administered betel leaf (Piperbetel leaf Linn.) on digestive enzymes of pancreas and intestinal mucosa and on bile production in rats. Indian J Exp Biol. 1995;33(10):752-756.

13. Pradhan D, Suri KA, Pradhan DK, Biswasroy P. Golden Heart of the Nature: Piper betle L. Journal of Pharmacognosy and Phytochemistry. 2013;1(6).

14. Ramji N, Ramji N, IyerR, Chandrasekaran S, 2002. Phenolic antibacteria from Piper betle in the prevention of halitosis. J Ethnopharmacol. 2002;83(1-2):149-152.

15. Sugumaran M, Suresh Gandhi M, Sankarnarayanan K, Yokesh M, Poornima M, Sree Rama rajasekhar, Chemical composition and antimicrobial activity of vellaikodivariety of Piper betle Linn Leaf oil against dental pathogens. Int J PharmTech Res. 2011;3(4):2135-2139.

16. Datta A, Ghoshdastidar S, Singh M. Antimicrobial Property of Piper betel leaf against Clinical Isolates of Bacteria. IJPSR. 2011;2(3):104109.

17. Kaveti B,Tan L, Antibacterial Activity of Piper betle Leaves. International Journal of Pharmacy Teaching and Practices. 2011;2(3):129-132.

18. Chakraborty D, Shah B. Antimicrobial, anti-oxidative and antihemolytic activity of Piper betel leaf extracts. IJPPS. 2011;3(3):192199.

19. Das S, Parida R, Sriram Sandeep I, Nayak S, Mohanty S. Biotechnological intervention in betelvine (Piper betle L.): A review on recent advances and future prospects. Asian Pac J Trop Med. 2016;9(10):938-946. doi:10.1016/j.apjtm.2016.07.029

20.Trakranrungsie N, Chatchawanchonteera A, Khunkitti W Ethnoveterinary study for anti-dermatophytic activity of Piper betle, Alpinia galangal and Allium ascalonicum extracts in vitro. Res Vet Sci. 2008;84(1):80-84.
21. Sharma KK, Saikia R, Kotoky J, Kalita IC, Das J. Evaluation of Antidermatophytic activity of Piper betle, Allamanda cathertica and their combination: An in vitro and in vivo study. Int J PharmTech Res. 2011;3(2):644-651.

22. Sharma R. Pathogenecity of Aspergillus niger in plants. Cibtech Journal of Microbiology. 2012;1(1):47-51.

23. Wilson CL, Wisniewski ME. Biological control of postharvest diseases of fruits and vegetables: an emergency technology. Annual Review of Phytopathology. 1989;27:425-441. doi: 10.1146/annurev. py.27.090189.002233

24. Laundon GF, Rainbow AF. Cerotelium fici. CMI Descriptions of Pathogenic Fungi and Bacteria. 1971;281:1-2.

25. Deshpande SN, Kadam DG. GCMS analysis and antimicrobial activity of Piper betle (Linn) leaves against Streptococcus mutans. Asian J Pharm Clin Res. 2013;6(5):99-101.

26. Basak S, Guha P. Modelling the effect of essential oil of betel leaf (Piper betle L.) on germination, growth, and apparent lag time of Penicillium expansum on semi-syntheticmedia. IntJFood Microbiol.2015;215:171178. doi:10.1016/j.ijfoodmicro.2015.09.019

27. Carrasco AH, Espinoza CL,Cardile V, Gallardo C, Cardona W, Lombardo L, Catalán MK, Cuellar FM, Russo A. Eugenol and its synthetic analogues inhibit cell growth of human cancer cells (Part I.). Journal of the Brazilian Chemical Society. 2008;19:543-548.

28. Paranjpe R, Gundala SR, Lakshminarayana N, Sagwal A, Asif G, Pandey A, et al. Piper betel leaf extract: anticancer benefits and bioguided fractionation to identify active principles for prostate cancer management. Carcinogenesis. 2013;34(7):1558-1566. doi: 10.1093/ carcin/bgt066

29. Prakash B, Shukla R, Singh P, Kumar A, Mishra PK, Dubey NK. Efficacy of chemically characterized Piper betle L. essential oil against fungal and aflatoxin contamination of some edible commodities and its antioxidant activity. Int J Food Microbiol. 2010;142(1-2):114-119.

30. Saxena M, Khare NK, Saxena P, Syamsundar KV, Srivastava SK. Antimicrobial activity and chemical composition of leaf oil in two varieties of Piper betle from northern plains of India. JSIR. 2014;73(2):95-99.

31. Rawat S. Food Spoilage: Microorganisms and their prevention. Asian J. Plant Sci. Res. 2015;5(4):47-56.

32. Adeyeye SAO. Fungal mycotoxins in foods: A review. Cogent Food \& Agriculture. 2016;2(1). doi: 10.1080/23311932.2016.1213127

33. Ali I, Khan FG, Suri KA, Gupta BD, Satti NK, Dutt P, et al. In vitro antifungal activity of hydroxychavicol isolated from Piper betle L. Annals of Clinical Microbiology and Antimicrobials. 2010;9:1-7. doi: 10.1186/1476-0711-9-7

34. Sharma S, Khan IA, Ali I, Ali F, Kumar M, Kumar A. et al. Evaluation of the Antimicrobial, Antioxidant, and Anti-Inflammatory Activities of Hydroxychavicol for Its Potential Use as an Oral Care Agent. Antimicrobial Agents and Chemotherapy. 2009;53(1):216-222. doi:10.1128/AAC.00045-08

35. Gundala SR, Yang C, Mukkavilli R, Paranjpe R, Brahmbhatt M, Pannu V. et al. Hydroxychavicol, a betel leaf component, inhibits prostate cancer through ROS-driven DNA damage and apoptosis. Toxicol Appl Pharmacol. 2014;280(1):86-96. doi: 10.1016/j.taap.2014.07.012

36. Deshpande SN, Kadam DG. Evaluation of antimicrobial activity of extracts of Piper betle (Linn) leaves against Streptococcus mutans. World Journal of Pharmacy and Pharmaceutical Sciences. 2015;4(11):1040-1050.

37. Singtongratana N, Vadhanasin S, Singkhonrat J. Hydroxychavicol and Eugenol Profiling of Betel Leaves from Piper betle L. Obtained by Liquid-Liquid Extraction and Supercritical Fluid Extraction. Kasetsart J (Nat Sci). 2013;47:614-623. 